\title{
A RESTUDY OF TWO ANTS FROM THE SICILIAN AMBER
}

\author{
By William L. Brown, JR. ${ }^{1}$ AND Frank M. Carpenter ${ }^{2}$
}

\section{INTRODUCTION}

The ants of the (presumably Miocene) Sicilian Amber were monographed by Emery (1891), and, except for corrections published by Emery himself (1913), this faunule has not again been subjected to critical study. Since 1891, of course, formicid taxonomy has undergone radical changes, some of them affecting genera found in this amber. Ectatomma gracile, for example, was described from a male specimen that would not today be placed in Ectatomma, but instead, as based on Emery's description (1891:571) and figures (P1. 1, fig. 1,2) is assignable to Gnamptogenys (Kugler and Brown, in prep.).

It is not our purpose here, however, to review all of Emery's Sicilian Amber ants. Rather, we want to present the results of our study of just two of his type specimens that are particularly significant for ant taxonomy. The specimens, in two separate pieces of amber belonging to the Museo Mineralogico dell'Universitá degli Studi, Bologna, Italy, were lent through the kindness of Prof. Gianfranco Simboli, Director of the Museo Mineralogico, who has our thanks. The new preparation of the specimens and their photographs were done by FMC, while WLB is responsible for the taxonomic interpretation of the material.

\section{Hypopomyrmex bombiccii}

Emery, 1891:574-575, pl. 1, fig. 10, 11, alate queen.

This specimen (figs. 1,2) is a badly collapsed winged queen closely involved in the same piece of amber with a worker specimen of Cataulacus planicens. Emery, in his fig. 10, and especially fig. 11, portrays the $H$. bombiccii specimen as a Strumigenys-like individ-

\footnotetext{
'Department of Entomology, Cornell University, Ithaca, New York, 14853. Study aided by National Science Foundation Grant GB-31662.

${ }^{2}$ Museum of Comparative Zoology, Harvard University, Cambridge, Mass. Study aided by National Science Foundation Grant DEB78-09947, F.M. Carpenter, Principal Investigator.
}

Manuscript received by the editor May 30, 1979. 


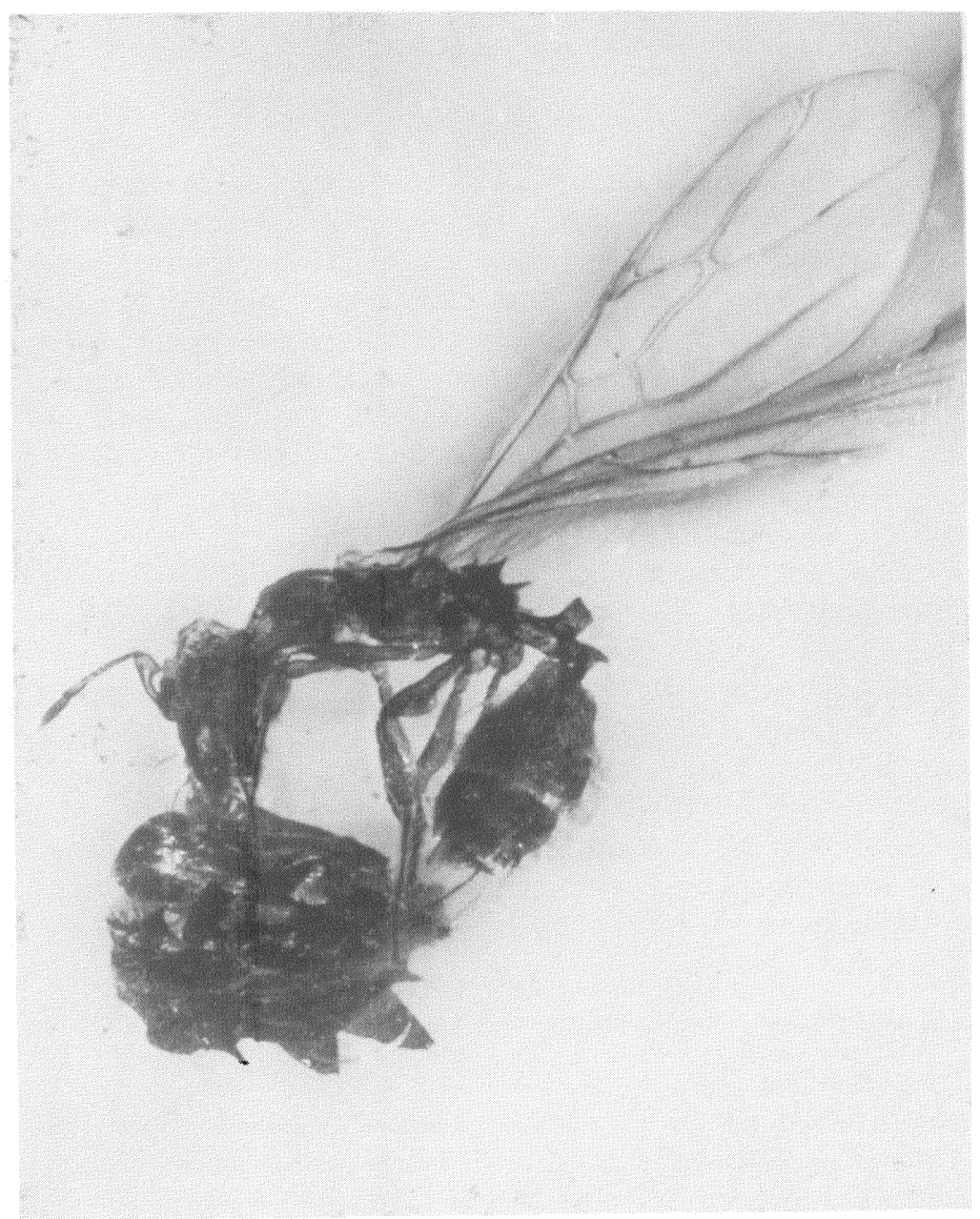

Figure 1. Hypopomyrmex bombiccii, type queen viewed from left side. Dark mass below queen is the curled type of Cataulacus planiceps. The view is essentially the same as portrayed by Emery (1891: pl. 1, fig. 10). Length of fore wing, $3.7 \mathrm{~mm}$. 


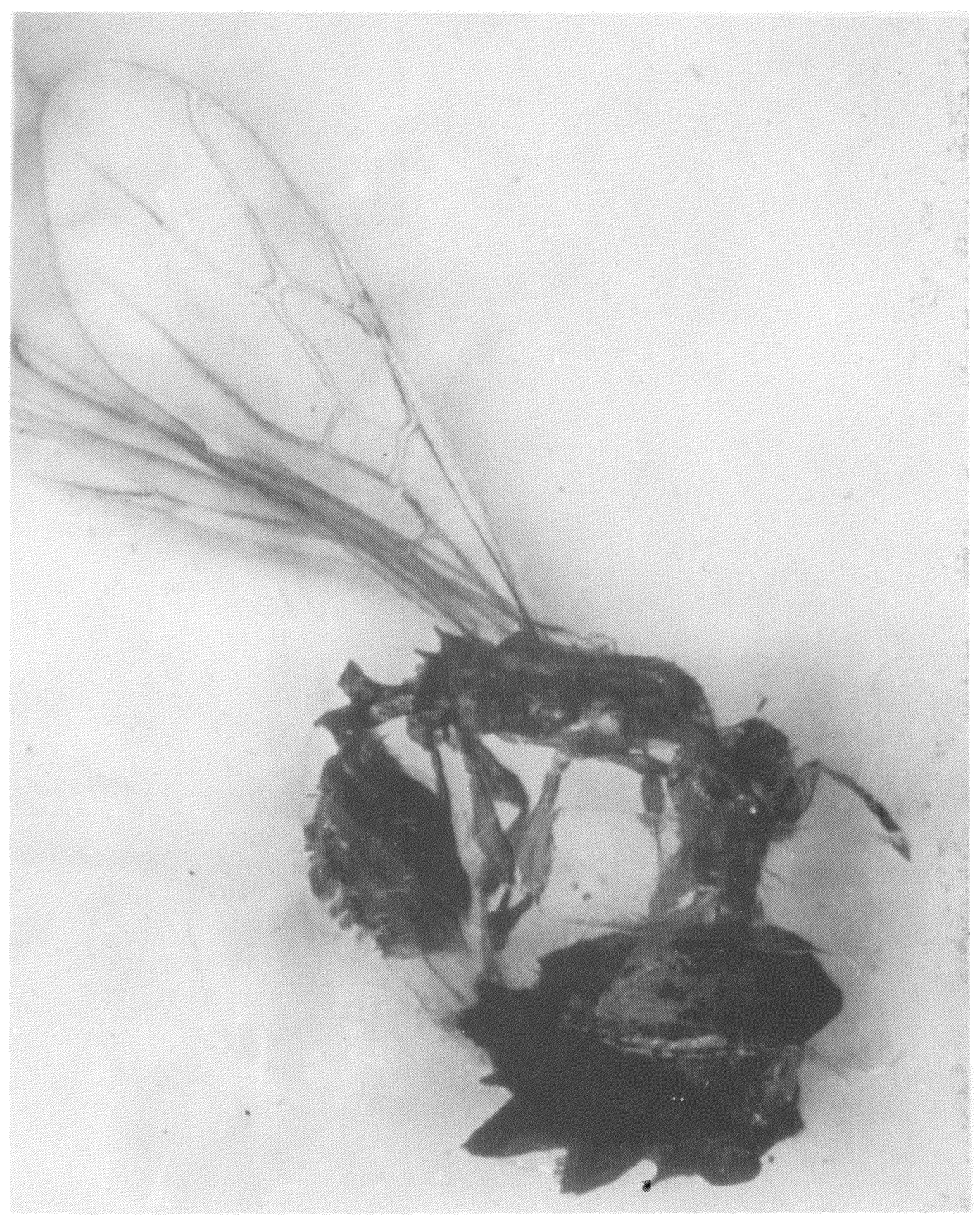

Figure 2. Hypopomyrmex bombiccii, type queen viewed from right side. Length of fore wing, $3.7 \mathrm{~mm}$. 


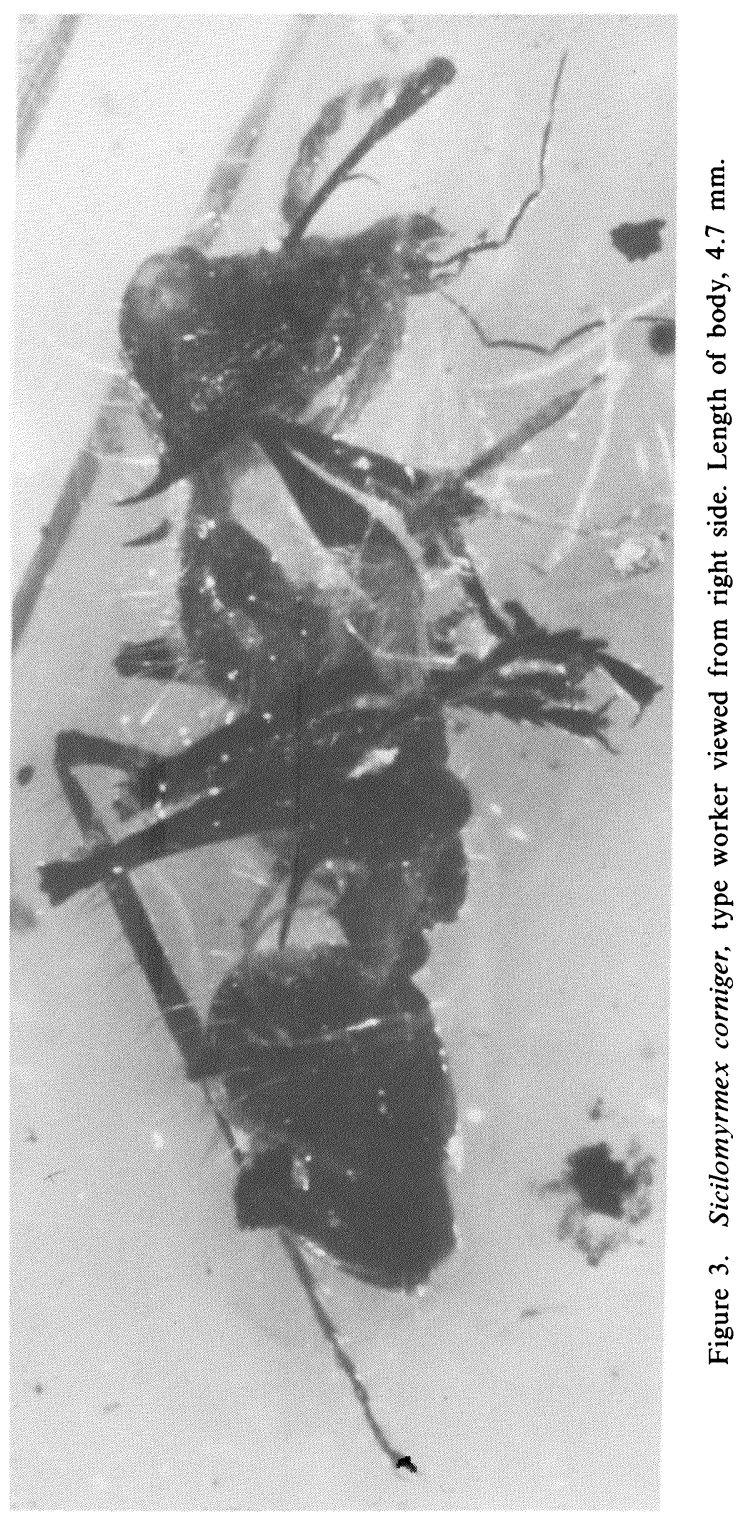




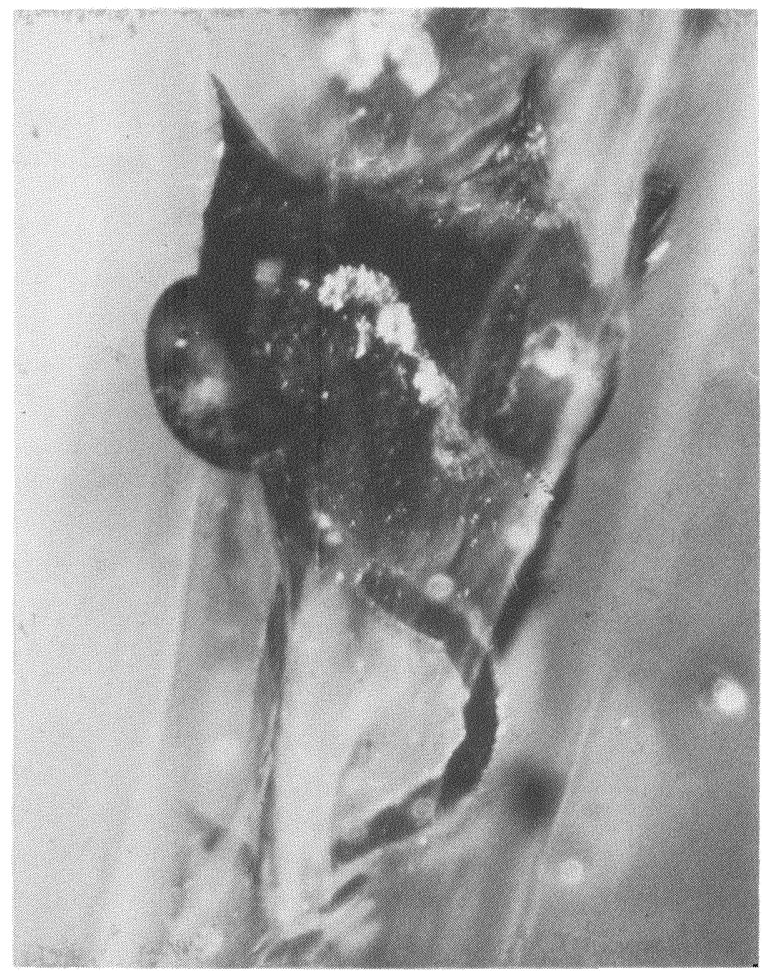

Figure 4. Sicilomyrmex corniger, type worker, dorsal (facial) view of head, tilted slightly forward. 
ual; a small eye is shown arising from beneath a scrobe-like head groove, and elongate mandibles are suggested in vague outline. The 10 -segmented antenna is depicted by Emery with a clearly 2-merous club and an apically thickened and sharply bent scape.

The amber piece has now been cleaned, partly re-ground, and somewhat cleared by injection of a small amount of Canada balsam. Figures 1 and 2 are photographs of the Hypopomyrmex bombiccii type, a winged queen, in the new preparation. The specimen is badly shrivelled and compressed, especially from side to side, and the petiolar and postpetiolar nodes are strongly compressed anteroposteriorly. It can now be seen that the Strumigenys-like cranial shape portrayed by Emery is really only his free interpretation of the crumpled head; the deformed left eye protrudes from the dorsolateral margin of the head, not from any scrobe, and the mandibles do not extend as Emery's figure 11 vaguely suggests they do. The right side view (fig. 2) of the head now available shows the right compound eye also distorted, but larger, more elliptical and less protruding than the left eye. The right antennal scape has its apex flattened, but not sharply bent like that of the left scape, indicating that the latter was distorted after death.

Hypopomyrmex is clearly not a member of tribe Dacetini. Habitus, wing venation and the form of the waist do place it in the subfamily Myrmicinae. The 10-merous antennae with 2-merous club, the forewing venation and the propodeal teeth make it most likely a member of the group of genera near Pheidologeton, and it may be regarded as a doubtful synonym of Oligomyrmex. The taxonomy of the living forms of this group is still so poorly known, and the fossil is in such poor condition that formal synonymy here would be premature.

It may be noted, however, that Oligomyrmex sophiae (=Aeromyrma sophiae), based on male specimens, was described by Emery from the Sicilian Amber in the same (1891) paper.

With the removal of Hypopomyrmex from the Dacetini, that tribe loses its entire known fossil history.

Sicilomyrmex corniger

Gesomyrmex corniger Emery 1891:581, pl. 3, fig. 33-35, worker.

This extraordinary formicine is portrayed in the photographs (figs. 3 and 4). Emery originally assigned it to Gesomyrmex, but the bicornuate head and two-spined propodeum clearly put it into a 
separate genus, as W.M. Wheeler realized in 1915, when he applied a new generic name in the combination Sicelomyrmex corniger. Unfortunately, the new genus name was one of several misspelled in this German wartime publication, which Wheeler apparently did not see in proof. He published the name in the emended form Sicilomyrmex in 1926, and again in 1928, but by 1929 he had reverted, perhaps absent-mindedly, to the spelling Sicelomyrmex, and even suggested for it a new tribe, Sicelomyrmicini. The tribal name was in any case improperly coined, since the stem involved is myrmec-, not myrmic-.

It would seem proper to recognize the emended spelling Sicilomyrmex of 1926 and 1928, since it is clear that Wheeler in 1915 was alluding to the provenience of the specimen from the Sicilian Amber, and that the original spelling Sicelomyrmex was therefore either a lapsus calami or a printer's error, according to Article 33(a)(ii) of the International Code of Zoological Nomenclature. The necessary emendation of the tribal name thus results in Sicilomyrmecini. Whether this tribe is worth retaining can only be decided after full revisionary study of the tribal classification of subfamily Formicinae.

Emery's original drawings of $S$. corniger were good ones, but we think that the first photographs of the type specimen (figs. 3 and 4) give an excellent idea of its habitus.

\section{ReFERENCES Cited}

EMERY, C.

1891. Le formiche dell'Ambra Siciliana. Mem. R. Accad. Sci. Ist. Bologna (5) 1:568-591, pl. 1-3.

1913. Le origini e le migrazioni della fauna mirmecologica d'Europa. Rend. Accad. Sci. Bologna, 1912-1913:29-46.

WHEELER, W. M.

1915. The ants of the Baltic Amber. Schrift. Phys.-ökon. Ges. Königsberg 55:1-142.

1926. Les sociétés d'insects. Paris, G. Doin et Cie; xii +468 pp.; cf. p. 136.

1928. The Social Insects. New York; Harcourt, Brace and Co., xviii +378 pp.; cf. pl. 18, fig. 27, facing p. 107.

1929. The identity of the ant genera Gesomyrmex Mayr and Dimorphomyrmex Ernest Andre. Psyche 36:1-12. 

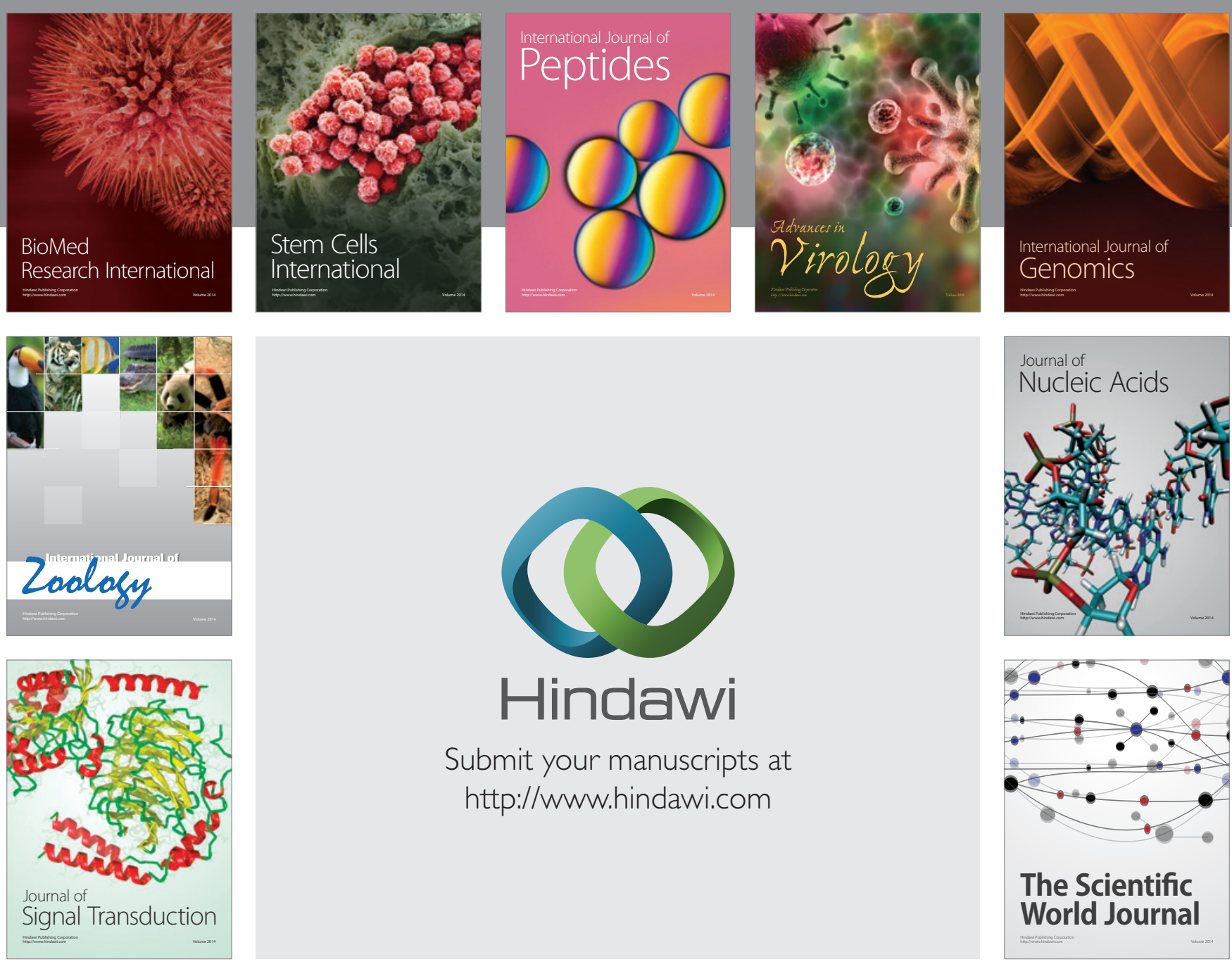

Submit your manuscripts at

http://www.hindawi.com
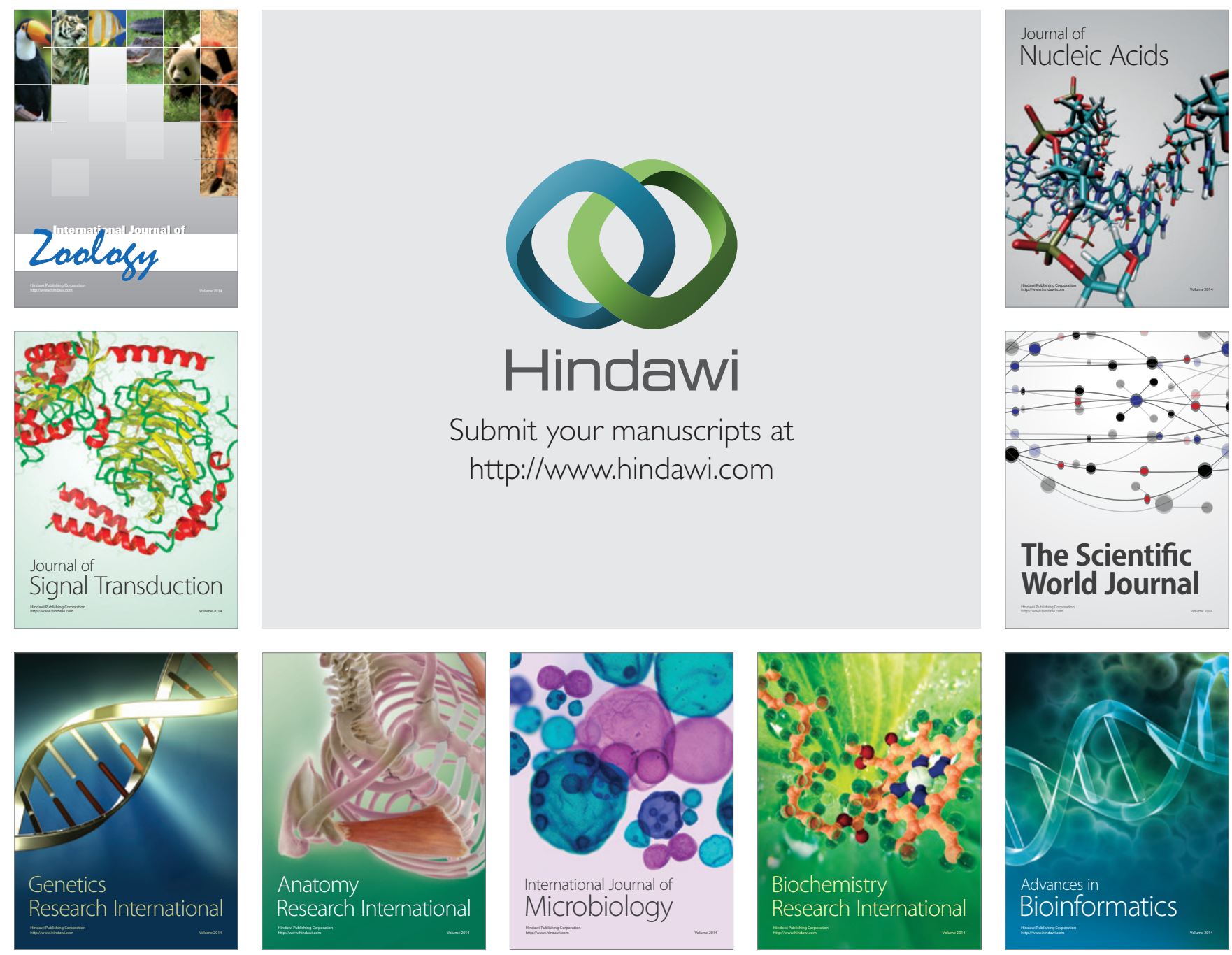

The Scientific World Journal
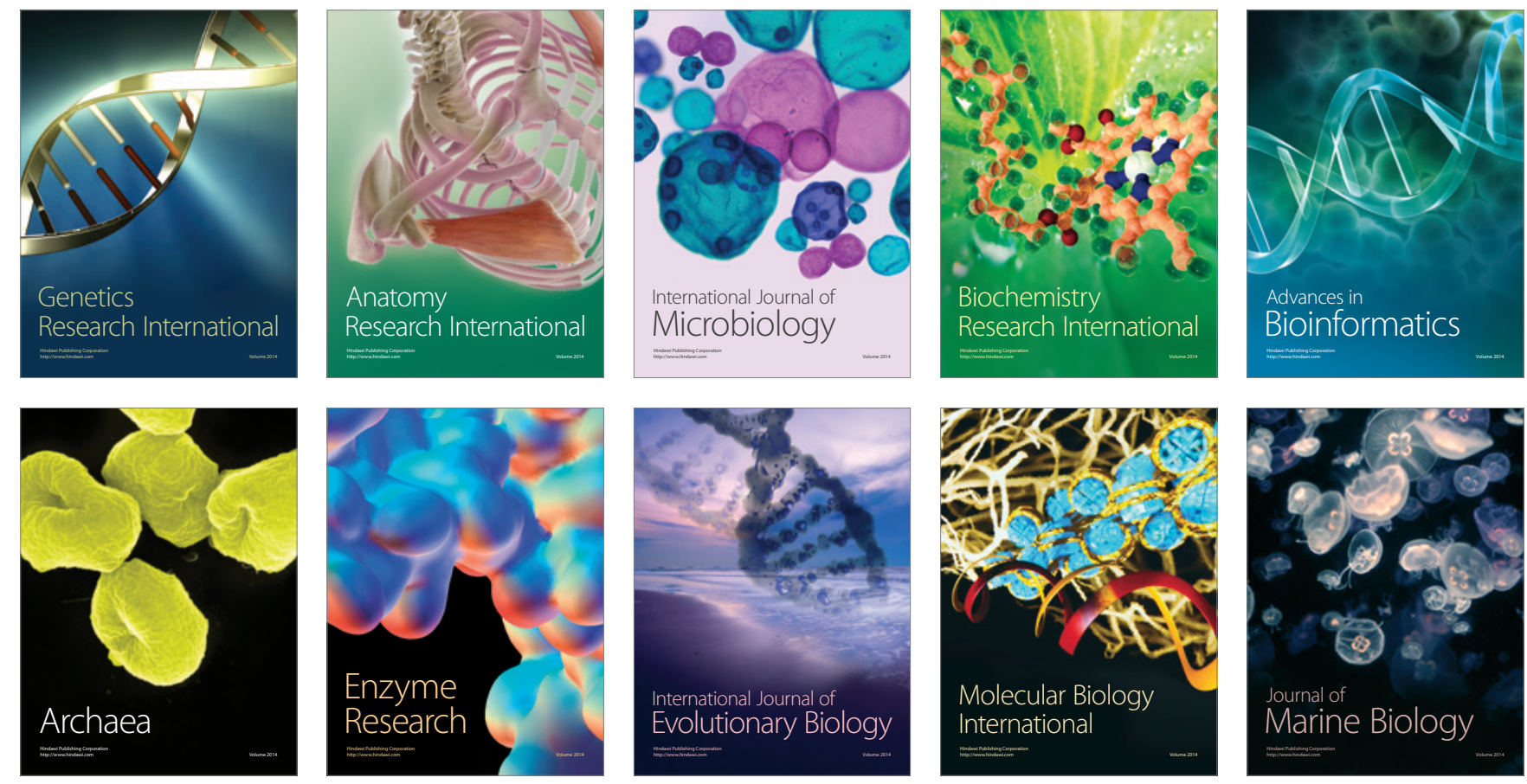